$$
\begin{aligned}
& \text { GHAWCOS IN OTHE FOCOS SUPPY } \\
& \text { AND TMLER RELATIONDO NUTRITION } \\
& \text { I.A PSTBUTHE 13. MENDEL }
\end{aligned}
$$

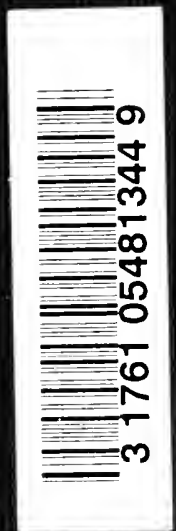




Digitized by the Internet Archive in 2007 with funding from Microsoft Corporation 
CHANGES IN THE FOOD SUPPLY AND THEIR RELATION TO NUTRITION 



\title{
Changes in The Food Supply AND THEIR RELATION TO NUTRITION
}

\author{
By \\ LAFAYETTE B. MENDEL \\ Professor of Physiological Chemistry in the Sheffeld \\ Scientific School of Yale University
}

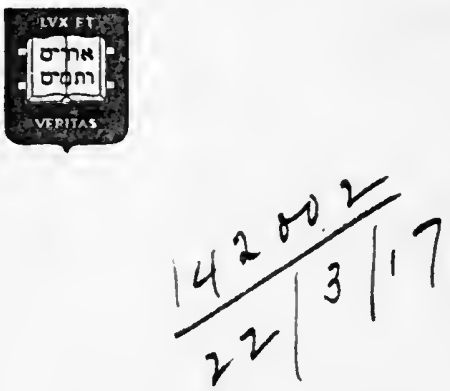

New Haven: Yale University Press

London: HuMphrex Milford

Oxford University Press

MDCCCCXVI 


\section{COPYRIGHT, 1916 \\ By Yale University Press}

First printed February, 1916, 1500 copies 


\section{PREFATORY NOTE}

This essay was written for the meetings of The Second Pan American Scientific Congress, at Washington, December, 1915.

\section{Lafayette B. MendeL}

Sheffield Scientific School, Yale University,

New Haven, Connecticut. 



\section{CHANGES IN THE FOOD SUPPLY AND THEIR RELATION TO NUTRITION}





\section{CHANGES IN THE FOOD SUPPLY AND THEIR RELATION TO NUTRITION}

"In the type of civilization with which we are most familiar there are two fundamental elements-supplies of food energy and supplies of mechanical energy. Since, at present, partly because of geographical conditions, these do not necessarily (or even in general) occur together, there is a third essential factor, the line of transport." A comprehensive consideration of any one of these factors, such as the food supply, cannot be completely dissociated from its relations to the others. The development of commerce among nations having adequate means of communication has, for example, rendered the distribution of food materials easy and developed a sense of security (under normal conditions)

1 Dickson, H. N.: The Redistribution of Mankind. Presidential Address to Section E (Geography) at the Birmingham meeting of the British Association, September, 1913. Report British Association for the Advancement of Science, Birmingham 1918, pp. 536-546. London 1914. 
against failure of food supplies. The growing organization of transportation facilities has encouraged the introduction of dietary changes never thought possible or even contemplated a few generations ago. Incidents associated with the altered distribution of wealth have improved the nutrition as well as other conditions of living among that large group of our population which has been termed the "healthier well-to-do classes."

The supply of food energy and its availability where needed are interrelated closely with a variety of factors, the bearing of which upon the problem at hand is not always evident upon the surface. Some of these features may be classified superficially as follows:

1. Food production.

2. Food preservation and food conservation.

3. Transportation facilities.

4. Customs in diet.

5. Changing industrial and social conditions, and other economic and hygienic factors.

Food Production.-The problem of food production is the fundamental concern of agriculture. 
How profoundly its practices are being changed by the progress of science and the mechanic arts is familiar to every observant person. The food supply has been increased in part through more intensive methods of agriculture, in part through the enormous extension of areas suitable for cultivation. In view of the increase of population it has been a favorite pastime for scientists to calculate the possibilities of the food supply of the future and to venture prophesies involving the prospect of impending failures. A forecast by Sir William Crookes of the relations between the probable increase of the world's supply and demand of wheat-cthe most sustaining food grain of the great Caucasian race"-was widely discussed when his estimates were published. In a Presidential Address to the British Association for the Advancement of Science in 1898 Crookes said:

Should all the wheat-growing countries add to their (producing) area to the utmost capacity, on the most careful calculation the yield would give us only an addition of some 
$100,000,000$ acres, supplying, at the average world yield of 12.7 bushels to the acre, $1,270,000,000$ bushels, just enough to supply the increase of population among bread eaters till the year 1931... Thirty years is but a day in the life of a nation. Those present who may attend the meeting of the British Association thirty years hence will judge how far my forecasts are justified.

Fifteen years later Professor Dickson said:

Half the allotted span has now elapsed, and it may be useful to inquire how things are going. Fortunately, this can be easily done, up to a certain point, at any rate, by reference to a paper published recently by Dr. J. F. Unstead, in which comparisons are given for the decades 1881-1890, 1891-1900, and 1901-1910. Dr. Unstead shows that the total wheat harvest for the world may be estimated at $2,258,000,000$ bushels for the first of these periods, 2,575,000,000 for the second, and $3,233,000,000$ for the third, 


\section{THEIR RELATION TO NUTRITION 5}

increases of 14 per cent and 25 per cent, respectively. He points out that the increases were due "mainly to an increased acreage," the areas being $192,000,000,211$,000,000 , and $242,000,000$ acres, but also "to some extent (about 8 per cent) to an increased average yield per acre, for while in the first two periods this was 12 bushels, in the third period it rose to 13 bushels per acre."

If we take the period 1891-1900, as nearly corresponding to Sir William Crookes's initial date, we find that the succeeding period shows an increase of $658,000,000$ bushels, or about half the estimated increase required by 1931, and that attained chiefly by "increased acreage."

But signs are not wanting that increase in this way will not go on indefinitely. We note (also from Dr. Unstead's paper) that in the two later periods the percentage of total wheat produced which was exported from the United States fell from 32 to 19, 
the yield per acre showing an increase meanwhile to 14 bushels. In the Russian Empire the percentage fell from 26 to 23 , and only in the youngest of the new countries-Canada, Australia, and the Argentine-do we find large proportional increases. Again, it is significant that in the United Kingdom, which is, and always has been, the most sensitive of all wheat-producing countries to variations in the floating supply, the rate of falling off of home production shows marked if irregular diminution.

Looking at it in another way, we find (still from Dr. Unstead's figures) that the total amount sent out by the great exporting countries averaged in 1881-1890, 295,000,000 bushels; 1891-1900, 402,000,000; 1901-1910, 532,000,000. These quantities represent, respectively, $13,15.6$, and 16.1 per cent of the total production, and it would appear that the percentage available for export from these regions is, for the time at least, approaching its limit-i.e., that 


\section{THEIR RELATION TO NUTRITION 7}

only about one-sixth of the wheat produced is available from surpluses in the regions of production for making good deficiencies elsewhere.

There is, on the other hand, abundant evidence that improved agriculture is beginning to raise the yield per acre over a large part of the producing area. Between the periods 1881-1890 and 1901-1910 the average in the United States rose from 12 to 14 bushels; in Russia, from 8 to 10 ; in Australia, from 8 to 10. It is likely that in these last two cases at least a part of the increase is due merely to more active occupation of fresh lands as well as to the use of more suitable varieties of seed, and the effect of improvements in methods of cultivation alone is more apparent in the older countries. During the same period the average yield increased in the United Kingdom from 28 to 32 bushels; in France from 17 to 20; Holland, 27 to 33; Belgium, 30 to 35 ; and 
it is most marked in the German Empire, for which the figures are 19 and 29.

In another important paper Dr. Unstead has shown that the production of wheat in North America may still in all likelihood be very largely increased by merely increasing the area under cultivation, and the reasoning by which he justifies this conclusion certainly holds good over large districts elsewhere. It is of course impossible, in the present crude state of our knowledge of our own plant, to form any accurate estimate of the area which may, by the use of suitable seeds or otherwise, become available for extensive cultivation. But $I$ think it is clear that the available proportion of the total supply from "extensive" sources has reached, or almost reached, its maximum, and that we must depend more and more upon intensive farming, with its greater demands for labor.

The average total area under wheat is estimated by Dr. Unstead as $192,000,000$ for 1881-1890, 211,000,000 acres for 1891- 


\section{THEIR RELATION TO NUTRITION 9}

1900, and 242,000,000 acres for 1901-1910. Making the guess-for we can make nothing better-that this area may be increased to $300,000,000$ acres, and that under ordinary agriculture the average yield may eventually be increased to 20 bushels over the whole, we get an average harvest of $6,000,000,000$ bushels of wheat. The average wheat eater consumes, according to Sir William Crookes's figures, about $41 / 2$ bushels per annum; but the amount tends to increase. It is as much (according to Dr. Unstead) as 6 bushels in the United Kingdom and 8 bushels in France. Let us take the British figure, and it appears that on a liberal estimate the earth may in the end be able to feed permanently $1,000,000,000$ wheat eaters. If prophecies based on population statistics are trustworthy, the crisis will be upon us before the end of this century. ${ }^{2}$

Interesting as such speculations are, despite the number of uncertain variables with which they 2 Dickson, H. N.: loc. cit., p. 538. 
necessarily deal, they fail to take into consideration the altered prospects arising out of the modern increasing knowledge of the science of nutrition. It is by no means improbable that progress in food chemistry and the study of metabolism will point the way to substitutes for what is now regarded as a staple foodstuff. We shall see what changing customs in diet have already brought about in many instances. If corn, for example, does not satisfy the requirement of a staple crop for human consumption, it is not at all unlikely, in view of information already available, that small addenda of other foods may suffice to supplement it so as to produce a more perfect ration. One may appropriately recall here that evidences of adequate nutrition are available from people nourished in most diverse ways in different parts of the world. Even if the wheat problem were to become one of urgency within an appreciable period, this need not necessarily be construed into a forecast of an actual shortage of food. Within a few months attention has been directed to the possibility of growing in the United States at 


\section{THEIR RELATION TO NUTRITION 11}

least two plant products which may serve as human foods. One of these is proso millet, the other grain sorghum or kaoliang, both of which have long been known in other parts of the world as constituents of the diet of mankind. Both of these seeds can be milled like the familiar cereals and served like these or transformed into culinary products after admixture with flour which enables them to be prepared for baking. The peculiar agricultural advantage in such crops lies in the fact that they are drought-resistant. Proso will grow when and where the staple small grains that require moist regions fail. Kaoliang represents a tropical annual plant which can, by cultivation, be extended north as far as Indian corn on this continent. The dietary possibilities of both proso and kaoliang have already been tested in a semipublic way. ${ }^{3}$

Food Preservation and Food Conservation.The preservation of food affects the food supply by making it possible to utilize in times and places

3 Hansen, N. E.: Proso and Kaoliang as Table Foods. South Dakota Agricultural Experiment Station, Bulletin 158, March, 1915. 
of relative scarcity products which are available in a season and region of abundance. From an early period preservative methods have been employed. Some of them are so familiar that they are frequently not even recognized as belonging in the category of food preservation. Desiccation, canning, pickling, salting, smoking, low temperature, freezing, special chemicals-these are some of the factors that enter into this aspect of our theme. The significance of most, if not all, of these procedures is more largely economic than hygienic.

The cold storage methods now in use represent a comparatively recent development of the preservation problem. According to Sherman, only since about 1893 have the quantities of food materials placed in cold storage been large enough to have an appreciable effect upon market conditions. As an illustration of its efficiency recent experiments have shown that fresh fish-a food product notably subject to speedy deterioration-may be preserved frozen, by the best cold 
storage processes, without undergoing any important change for at least two years."

Modern bacteriology has placed upon cleanliness a preservative value which may appear surprising in respect to its efficiency, particularly in conjunction with low temperatures which inhibit the development of micro-organisms detrimental to foods. As an example of what such sanitary precautions can accomplish in the case of readily deteriorating milk Sherman states that "three American dairy farms exhibited raw milk at the Paris Exposition of 1900, one of them sending weekly shipments throughout the summer, each of which was kept on exhibition in the raw state without spoilage until the next shipment arrived. It was difficult to convince the jury of European experts of the fact that 'cleanliness and cold' were the only preservatives needed to accom-

4 Smith, C. S.: A Study of the Influence of Cold-Storage Temperatures upon the Chemical Composition and Nutritive Value of Fish. Biochemical Bulletin, 1913, iii, 54; Perlzweig, W., and Gies, W. J.: A Further Study of the Chemical Composition and Nutritive Value of Fish Subjected to Prolonged Periods of Cold Storage. Ibid., 1913, iii, 69. 
plish the keeping of raw milk in a fresh, sweet condition for two to four weeks in midsummer." Precisely such methods, combined with modern transport facilities, have made it possible to extend the range of milk supply in our large cities literally hundreds of miles and to bring an indispensable food at a reasonable price into every home. There is, indeed, a profound difference between marketing milk in the familiar manner now practiced and the older mode of distribution when goats or cows were driven in front of the home to be milked there.

Probably no single preservation device excels that of desiccating the material. In the absence of moisture decay is arrested. Where the water content of a natural food is not unduly large it can often be dried readily with success. Dried meats, fish, and fruits have long belonged to the list of preserved foods. In the case of products comparatively rich in water, particularly liquid or semi-liquid foods, successful methods of desiccation have awaited the perfection which is begin-

s Sherman, H. C.: Food Products. New York 1914, p. 53. 
ning to manifest itself at the present day. Aside from the element of cost, the use of heat to expel moisture has the objection that it alters the product in some cases so that it is no longer dietetically acceptable. Heat also may remove desirable volatile ingredients. Flavors, which play a very important rôle in rendering a food acceptable to the consumer, are not always thermostabile. Modern industry is likely to overcome many of the difficulties by the device of desiccation at lower temperatures either in a vacuum or a current of air. A most satisfactory instance of this is seen in the case of milk. Condensed and evaporated milks are likely to be superseded by dried milk of which superior grades are already being manufactured. The successful desiccation of milk-a product of which seven-eighths is waterwith retention of the solubility on which the practical applications largely depend, and with its nutritive virtues presumably intact, is an up-todate accomplishment.

The possibility of a satisfactory outcome of the efforts now being made in the milk industry 
deserves more than a passing notice. Milk not only is a valuable food; it is at present an indispensable component of the diet during growth, and no entirely satisfactory method of preservation has hitherto been devised. With one American brand of dried milk as the chief component of the ration, several investigators, including myself, have raised small animals into a second generation. If the best dried milk of the future shall be shown to retain even the more subtle physiological properties, such as its antiscorbutic potency, it will represent good achievement.

The expression "food conservation" is used in the present discussion perhaps not in accord with a strict definition but rather in the broader current sense in which we speak of the conservation of other resources. The growing use of by-products finds its exemplification in the food industries as well as in other branches of commerce; and directly or indirectly this affects the problem of food supply. In some instances the use of the by-products has rendered profitable and therefore possible the production of a food which otherwise 


\section{THEIR RELATION TO NUTRITION 17}

could not be marketed advantageously. The meat industry presumably affords instances where the price of edible parts has been kept within reasonable limits by the increasing market value of what was once merely worthless refuse. Tankage belongs to the latter category. The refinement of this aspect of modern industry is exemplified when the fine hairs in the ears of cattle fattening for market are clipped for the special manufacture of expensive "camel's hair" brushes; and likewise in the careful removal and collection of the seeds from raisins introduced into commercial mince meat. From these supposedly worthless seeds valuable raisin oil is subsequently extracted. The by-products of the sugar industries are notably important. Part of them are literally used to get gold. The residues from the desaccharification factories are rich in nitrogen which is in part converted into sodium cyanide. Tons of this have been exported to the Transvaal, where it has been used for extracting the precious metal by the well-known cyanide process.

For the food supply it is more important that 
in many instances what was in the past regarded as refuse or a useless dietary constituent has been converted into edible products. Sometimes, as in the case of grain products, in the distilleries, breweries, etc., by-products now serve as cattle feeds and thus indirectly conserve the food supply of man. In other instances new human foods have been devised. Cotton seed oil, oleo oils from beef, and other fats are no longer despised as constituents of the diet. In some cases chemistry has aided to alter the fats into a suitable texture and consistency for culinary purposes. Slaughterhouse blood finds its way into food products. Corn sirups and glucose sugars artificially prepared from cheap sources of starch have survived the propaganda of prejudice and now represent one of the cheapest sources of wholesome nutriment. Deteriorated products such as old butter are "renovated" and returned into the food treasury. Hydrogenated fats are a modern innovation.

The digestive functions of man offer a barrier to the successful use of certain agricultural pro- 


\section{THEIR RELATION TO NUTRITION 19}

ducts as human nutrients. Complete digestion is a prerequisite to adequate nutrition. Cellulose, which is so widely distributed in plants, is unutilized by man because it is indigestible. It is theoretically conceivable, however, that cellulose can be converted into available carbohydrate by chemical procedures. Other plant constituents, wholesome in themselves, are often practically unutilized in the alimentary tract because they are protected by impervious coverings. In such cases the physical texture of the product is at fault. The alimentary utilization of the foodstuffs, particularly the indispensable proteins, in common foods such as the legumes and cereal grains is far below what pertains in most animal food products. Some presumably valuable vegetable proteins cannot be used as food by man because his digestive juices cannot get at them in the condition in which they are usually exhibited for use. Improved culinary methods and procedures for extreme comminution, particularly after desiccation, may alter this situation in coming years. A beginning has already been advo- 
cated by $H$. Friedenthal in the case of certain green vegetables. The growing use of nut products and nut pastes, and the widespread popularity of the readily digested "peanut butter," prepared from an article which is looked upon as difficult of digestion in its imperfectly comminuted form, shows what industries can do to overcome dietary prejudices or domestic ignorance, by enhancing palatability and digestibility.

Of all the foodstuffs, the proteins offer the most serious problem. They represent the indispensable staple for tissue construction; they are produced at the greatest expense. The quantitative aspects of the protein requirement of man have been warmly debated in recent years. One extreme view of the superiority and consequent liberal need of protein was expressed by Liebig ${ }^{6}$ as follows :

Everywhere throughout organized nature, where animal life is developed, we find the phenomena of life depending on the presence

B von Liebig, J.: Familiar Letters on Chemistry. 3d edition. London 1851. 


\section{THEIR RELATION TO NUTRITION 21}

of albumen. The continuance of life is indissolubly connected with its presence in the blood, that is, in the nutrient fluid. In so far as the notions of formation, nutrition, or the nutritive property are inseparable from that of a substance, whose properties and composition are collected in the word albumen; only those substances are in a strict sense, nutritious articles of food, which contain either albumen, or a substance capable of being converted into albumen (p. 346).

The "plastic foods" of Liebig were the proteins. Accordingly he says again:

All these organized tissues, all the parts, which in any way manifest force in the body, are derived from the albumen of the blood; all the albumen of the blood is derived from the plastic or sanguigenous constituents of the food, whether animal or vegetable. It is clear, therefore, that the plastic constituents of food, the ultimate source of which is the vegetable kingdom, are the conditions 
essential to all production or manifestation of force, to all those effects which the animal organism produces by means of its organs of sense, thought, and motion (p. 366).

The other extreme is represented by the modern so-called "low protein" advocates. From the debate of this topic it has become probable that although some views as to the importance of protein in the dietary have been exaggerated, a liberal factor of safety must be allowed. In any event, protein has lost the special significance which it assumed in Liebig's day as the unique source of energy. As a guide in the consideration of the protein supply of the future we may recall the attitude of Professor Rubner, an expert in the field of nutrition study, before the Fifteenth International Congress on Hygiene and Demography at Washington in 1912 :

Nutrition in the cities has at all times a tendency toward refinement, but in former times, when the classes lived strictly separate, the food materials were also very dif- 


\section{THEIR RELATION TO NUTRITION 23}

ferent within the city walls. The food of the nobility was different from that of the middle class, and the latter from that of the poor people. Among the materials successfully used in the culinary art a high place has always been held by the meat of mammals, fowls, and fishes. These meats were the chief part of the meal, other foods of vegetable origin, as salads and vegetables, sweets and flour foods being added. Bread remained in the background. The traditions of this culinary art have remained the same down to our days. This diet of the upper classes is the only one which provides the pleasures of the table, it is rich in proteid and fat, it is not voluminous, does not overburden the stomach, tends less to obesity than any other diet, keeps the body even of a lazy man in good condition, and does not overwork the digestive functions. The less well-to-do reduce, of course, the amount of meat, but they use in its place bread and potatoes. This is called a mixed diet. When 
the barriers between the classes fell, the middle classes gradually rose to the more luxurious food of the formerly privileged classes.

It is a fact that the diet of the well-to-do is not in itself physiologically justified; it is not even healthy, for, on account of false notions of the strengthening effect of meat, too much meat is used by young and old and by children, and this is harmful. But this meat diet is publicly sanctioned; it is found in all hotels, it has become international and has supplanted almost everywhere the characteristic local culinary art. It has also been adopted in countries where European culinary art was unknown. Long ago the medical profession started an opposition to the exaggerated meat diet, long before the vegetarian propaganda was started. It was maintained that flour-foods, vegetables, and fruit should be eaten in place of the overlarge quantities of meat.

The descendants of those well-nourished classes are, on account of many influences, 


\section{THEIR RELATION TO NUTRITION 25}

especially the school and the indoor life, not always the strongest part of the nation, but since in recent times bodily exercises have become general, they are again decidedly in the ascendency.

The sanitary conditions of the great mass of industrial workers and their children, and of people of very small earnings, are different. Here we find a decided deterioration of the body, as is amply shown by the recruiting for military purposes. In spite of continuous migration from the country to the cities, conditions are little changed. The social surroundings of a great city are decidedly unfavorable to the maintenance of a strong race. Among the many factors which cause this decrease of bodily efficiency nutrition is not the least.

The industrial workers coming from the country to the city cannot well get along with their former simple diet, because the cheap food materials which are easily obtained, as bread and potatoes, contain too 
little proteid. They undoubtedly need an increase of proteid material. Neither can they find in the city the food conditions to which they had formerly been used; but they accommodate themselves rapidly to new conditions, coming into the new surroundings, as they usually do, without a family. Just as, under the doctrine of political equality, the lower classes try to attain the luxurious table of the well-to-do, so it is not surprising that industrial workers, coming from the country to the cities, accommodate themselves to the new dietary forms.

The workingman does not want proteid, leguminous food, milk, etc., to improve his vegetable diet; he wants simply meat, not because he needs it, but because it is for him a matter of pride to follow as best he can the other classes in his diet. The diffculty is that the cost of meat is considerably higher than in the country, where food can usually be obtained without the aid of deal- 


\section{THEIR RELATION TO NUTRITION 27}

ers, and where many foodstuffs are raised on one's own land.

The importance of the conservation of protein had led to numerous investigations of the economy of this foodstuff which need not be discussed here. ${ }^{7}$

Transportation Facilities.-The concentration of population in restricted areas is necessarily limited by the possibilities of the food supply. The latter is the corollary of finding suitable accommodations for increasing numbers. Within less than a century nearly every region of the globe has been tapped by railways or water-way facilities to permit the more uniform distribution

7 The following is a partial list of monographs dealing with some aspects of this topic: Chittenden, R. H.: Physiological Economy in Nutrition, 1904; Chittenden, R. H.: The Nutrition of Man, 1907; McCay, D.: The Protein Element in Nutrition, 1912; Rubner, M.: Volksernährungsfragen, 1908; Rubner, M.: Wandlungen in der Volksernährung, 1913; Hindhede, M.: Protein and Nutrition, 1913; Rubner, M.: Ueber moderne Ernährungsreformen, 1914; Mendel, L. B.: Theorien des Eiweissstoffwechsels nebst einigen praktischen Konsequenzen derselben, Ergebnisse der Physiologie, 1911, xi, 418-525; Mendel, L. B.: Nutrition and Growth. Harvey Society Lectures, 1914-15. 
of things. The competition of the different lines of transportation has been an interesting phase in the exchange of commodities, among which food has been conspicuous. The end is not in sight; for with the added possibility of preserving foods at reasonable cost, a new chance for distribution has arisen. American wheat has long traversed a continent by train or crossed an ocean in a steamer's hold; but the sight of Australian meats in the London market, of Californian fruits and vegetables in Boston, of eggs from China in Chicago, or of Wisconsin milk in Manila was reserved for the present generation. In earlier days the dietary habits of peoples were developed on the basis of the native products of the soil. Now, when the means of transportation are no longer primitive, specific demands can readily be satisfied by importation. This is particularly exemplified where certain habits of taste have persisted longer than the local sources of supply.

Customs in Diet.-To one who has given little thought to the subject, the dietary habits of a community or nation may appear as something 


\section{THEIR RELATION TO NUTRITION 29}

fairly fixed from generation to generation. This is, however, far from a correct view. Adequate nutrition may be exemplified alike among the meat- and blubber-eating Eskimos and the strictly vegetarian Hindoos. But particularly where the dietary instincts have led mankind to adopt a more diversified mixed ration one may discover shifts of custom and changes of eating habits within comparatively short periods. A comprehensive survey of this feature of dietetics and an examination of the underlying causes would furnish interesting physiological, sociological, and economic details. A few typical illustrations must suffice to indicate these interrelations between customs in diet and the food supply.

The use of fresh fruits has been enormously extended among the progressive peoples of temperate zones within the past two decades. Some of these food products, such as orchard fruits, have long been favorites in the dietary and because of their superior keeping qualities have been available over long periods of the year. The output of orchard fruits has kept pace with the growth 
of population. The value of the products of the orchard in the United States, in 1840, was about $\$ 8,000,000$; a recent census report gives the figure $\$ 140,867,000$. Among other types of fruits proportionately greater increases are noted. "Small fruits" contributed $\$ 30,000,000$; grapes, $\$ 22,000,000$; citrus fruits, $\$ 23,000,000$; other tropical and subtropical fruits, $\$ 2,000,000$; to the production of fruits in the United States in 1909. Many of these, like the orange and grapefruit, have become prominent in the diet of the well-to-do because of the readiness with which they can be obtained at a reasonable price everywhere during most of the year. Science, the mechanic arts, and business organization have combined to revolutionize the distribution and marketing, as one may learn in studying the work of the California Fruit-Growers' Exchange. The once enormous losses from decay have been greatly reduced and the marketed products are of a superior quality.

There is a physiological justification for the increasing prominence of fruits in the diet of the 


\section{THEIR RELATION TO NUTRITION 31}

better classes and its extension throughout all seasons of the year. With the growing use of highly digestible foods and the exclusion of indigestible food residues, with the widespread employment of milled cereals largely freed from cortical parts, with the tendency to exclude the "coarser" vegetables or limit their inclusion in the menus of the better classes, the absence of "roughage" in the diet combined with other features of modern living helps to induce habitual constipation in certain classes of society. The fruits serve a useful purpose in counteracting this tendency by promoting the movement of the bowel-hence the expression: "An apple a day keeps the doctor away."

The familiar adage just quoted has been converted into an advertising slogan in some of the apple-growing states of the West. This leads me to call attention to the potent force of advertising in creating a demand for food products of most varied sorts. The same agency which has created a nation-wide mania for chewing-gum and has initiated in all ranks of society a senseless habit 
of mastication which was, until a few years ago, limited to the overlooked improprieties of childhood, has been reflected in the food market. The ready-to-eat "breakfast foods" in highly advertised, neat and attractive packages have replaced the less expensive cereals long sold in bulk. The change is not merely one of the container or package; the contents no longer are the same. Oatmeal, for example, has lost some of its former popularity as a breakfast dish through the inroad of cornflakes and wheat foods. The breakfast staples have been changed by the modern advertiser; and illustrations of his ingenuity might be extended to include numerous food products. Except from the standpoint of extreme economy the innovations have as a rule been wholesome and usually in the interest of food hygiene. The purity of the products has not infrequently surpassed the honesty of the advertisement.

Most of us can recall the days when meat or eggs, or both, formed an indispensable part of the early meal, in the United States. At present there are signs everywhere, at least among those classes 


\section{THEIR RELATION TO NUTRITION 33}

which are not engaged in more vigorous muscular work, of a simplification of this meal by the exclusion of meat and the substitution of cereals and fruits. This is an approach to the traditional breakfast of continental Europe. It is not easy to analyze the underlying causes for such dietary changes; they are not solely physiological nor economic in origin. Rubner has remarked that sometimes revolutions occur in the field of popular nutrition. The introduction of the potato in many extensive regions is cited as an illustration.

It might be supposed that bread, "the staff of life," remains essentially what it has been in days gone by. This food product, however, furnishes an example of the evolution of a food industry. Bread making is gradually becoming a factory problem. The magnitude of this may be appreciated from the statement that the baking industry is today capitalized at over $\$ 270,000,000$; yet housekeepers still make 70 per cent of the product used. ${ }^{8}$ With increasing efficiency and

8 These statistics and related statements are taken from Duncan, R. K.: Some Chemical Problems of Today. New York, 1911. Chapter on Bread. 
range of distribution the use of bakers' bread is certain to increase; just as butter, pickles, mustard, etc., are no longer exclusively home-made products. As soon as larger corporate interests become involved in the food industries, altered methods of manufacture are likely to be introduced when they seem both profitable and feasible. Food innovations are not readily introduced in the home; but in the factory they frequently become questions of dollars and cents. In the manufacture of baked goods the cost of production has been modified by the substitution of dried milks for fresh milk, and of vegetable fats for the more expensive butter. The manufacture of yeast has become specialized into an important industry which reacts upon the public with the cleverly advertised admonition to "eat more bread."

Wheat has unique properties which adapt it to the production of bread as we now know it. Other seeds are competing for recognition. New "flours" are proposed. The proso and kaoliang flours already mentioned are among them. Even cotton seed "flour" is clamoring for recognition. When 


\section{THEIR RELATION TO NUTRITION 35}

glutenous adjuvants are supplied to cereals which lack them, and when more science is infused into the art of baking, new bakery products are likely to arise.

The use of fats in the diet is doubtless increasing in the United States. It is estimated that the consumption of butter alone reaches 23 to 24 grams (3/4 to $4 / 5$ of an ounce) or approximately 200 calories per person per day. An inspection of the dietaries in the public establishments of half a century ago, as they are reported in the treatises of that period, ${ }^{\circ}$ reveals the important part taken by bread in the regimen. Butter was often entirely omitted in the daily allowances of asylums, prisons, military groups, and other typical institutions. Frequently the diet lists of those days call for bread and molasses or bread and milk. Bread without butter or some other fat is now the rarity, at any rate in American homes. Despite the discouragement which the oleomar-

- For example, in Pereira, J.: A Treatise on Food and Diet. New York 1843. 
garine industry has received from legislation, ofttimes unwarranted, the use of butter substitutes is spreading as the price of the original product is increasing. Here too the advertising bill-boards are already pointing out the future way. Butter substitutes are not only used directly in the meal, but are finding a wide field of application in the cooking and baking processes of the kitchen.

Another change in diet customs is seen in the growing use of cheese in American homes. This wholesome article has long been appreciated at higher value in European countries than in our own. Nuts and nut foods are becoming more popular, in part as the result of the modern vegetarian propaganda which recommends them as "meat substitutes." The value of the peanut crop is about $\$ 20,000,000$. Sherman remarks that "to speak of nuts as 'meat substitute' is natural under present conditions and reflects the prominence which has been given to meat and the casual way in which nuts have been regarded for some generations. Looking at the matter in evolutionary 


\section{THEIR RELATION TO NUTRITION 37}

perspective it might be more logical to speak of meats as 'nut substitute' instead."

The current extensive use of sucrose in the form of refined cane sugar or beet sugar exemplifies what the cheapening of an article of commerce can accomplish in the field of diet. Although sucrose has a considerable fuel value in the organism its dietary use is primarily dictated by considerations of flavor. Opinions are occasionally divided as to the place of this sugar in the dietary. It seems as if the extremes of refinement which have made commercial sucrose in a chemical sense the purest of all purchasable foodstuffs had exceeded all requirements of nutrition or dictates of the palate. The addition of a blue dyestuff to give a white appearance to the final product represents one of the psychological values which are often more ridiculous than costly. Surely for most uses the artificially colored white sugar has nothing except a false standard to recommend it in place of the natural creamcolored sugar.

It is likely that the succulent vegetables will 
play a larger part in the table of American households. Dr. C. F. Langworthy, Chief of the Office of Home Economics in the States Relations Service at Washington, says :

One of the marked differences between the daily fare today and that of fifty years ago consists in the increased supply of green and succulent vegetables, a class of food used, as their names imply, for their refreshing and palatable qualities more than for their total nutritive value. Not many years ago the winter's supply of vegetables in all southern countries was limited to root crops and a few other staples, such as onions and cabbage, which could be kept in the cellar in comparatively good condition. New and improved varieties, better methods of cultivation, improvements in transportation and storage, the greater development of market gardening under glass, and the development of the canning and preserving industry, have made succulent vegetables common through- 


\section{THEIR RELATION TO NUTRITION 39}

out the year and available in one form or another for almost every family. ${ }^{10}$

The popularity of green vegetables is beginning to be reflected in the canning industries where the variety of such products is being extended rapidly and the canning process has already developed into an important enterprise. To the more familiar commercial lists including tomatoes, corn, peas, and beans, there are being added asparagus, beets, okra, pumpkin, sweet potato, rhubarb, sauerkraut, spinach, and squash. The extent of this canning industry and its growth in a single decade is shown statistically, as follows :

10 Langworthy, C. F.: Green Vegetables and Their Uses in the Diet. American Food Journal, October 15, 1912, p. 5. 
Extent of the Canning Industry in the United States ${ }^{11}$

Quality and Value of Food Canied, 1899, 1909

Cases ${ }^{1909}$ Valus Cases ${ }^{1899}$ Valus

Vegetables...... $\quad 32,752,469 \quad \$ 51,568,914 \quad 19,323,730 \quad \$ 28,734,598$

$\begin{array}{llllll}\text { Tomatoes..... } & 12,909,986 & 18,747,941 & 8,700,538 & 13,666,560\end{array}$

$\begin{array}{llllll}\text { Corn ......... } & 7,451,265 & 10,332,136 & 6,336,984 & 8,191,383\end{array}$

$\begin{array}{lllll}\text { Peas.......... } & 5,901,703 & 10,247,363 & 2,543,722 & 4,465,673\end{array}$

$\begin{array}{lllll}\text { Beans ........ } 3,392,864 & 6,013,098 & 1,493,517 & 2,025,123\end{array}$

Asparagus .... $\quad 228,559 \quad 1,975,775$

$\begin{array}{lllll}\text { Pumpkin } \ldots . . . & 440,303 & 576,043 & 138,078 & 202,404\end{array}$

Sweet potatoes $347,286 \quad 531,651 \quad 83,526 \quad 124,245$

$\begin{array}{llllr}\text { All other....... } & 2,080,503 & 3,144,907 & 27,365 & 59,210\end{array}$

$\begin{array}{llrlr}\text { Fruits } \ldots \ldots \ldots \ldots & 5,518,999 & 12,938,474 & 4,467,817 & 11,311,062\end{array}$

$\begin{array}{lllll}\text { Peaches....... } & 1,484,808 & 3,753,698 & 1,449,356 & 4,283,165\end{array}$

$\begin{array}{lllll}\text { Apples ........ 1,205,742 } & 1,898,720 & 645,762 & 1,125,119\end{array}$

$\begin{array}{lllll}\text { Apricots } \ldots \ldots & 630,185 & 1,825,311 & 531,648 & 1,538,252\end{array}$

$\begin{array}{lllll}\text { Pears ......... } & 637,782 & 1,833,214 & 672,485 & 2,188,201\end{array}$

$\begin{array}{lllll}\text { Berries ....... } & 815,851 & 1,754,927 & 600,419 & 1,092,975\end{array}$

$\begin{array}{lllll}\text { Cherries } \ldots \ldots & 390,351 & 1,019,013 & 114,367 & 307,788\end{array}$

All others.... $\quad 354,280 \quad 853,591 \quad 453,780 \quad 730,562$

The indirect effects of the anti-alcohol campaign now vigorously conducted in many countries are seen in the stimulation of trade in so-

11 Bitting, A. W.: Methods Followed in the Commercial Canning of Foods. U. S. Department of Agriculture, Bulletin 196, Washington 1915. 


\section{THEIR RELATION TO NUTRITION 41}

called temperance drinks. It comes as a surprise to an "old timer" to see buttermilk retailed over the bar of the American saloon. The grape juice industry has grown by leaps and bounds; and this alcohol-free natural product is veritably becoming one of the national drinks. I am informed from expert sources that the production of American unfermented grape juice in the year 1914 amounted to 4,593,750 gallons in the Chautauqua belt alone. Other fruits also are likely to figure in the new field of use here opened. It is stated that twenty-five per cent of the apples grown in American orchards never enter into the food supply of the nation. This has been a stimulus to the food conservationists to transform the unused materials into new forms of food. Apple sirup and concentrated cider have been suggested as new products for utilizing surplus and cull apples. ${ }^{12}$ The expert of the Department of Agriculture remarks :

12 Gore, H. C.: Apple Sirup and Concentrated Cider: New Products for Utilizing Surplus and Cull Apples. Yearbook of the Department of Agriculture for 1914, Washington 1915, p. 227. 


\section{CHANGES IN FOOD SUPPLY}

What the commercial future of the two products will be remains to be determined under actual marketing conditions. The departinent has every confidence in the feasibility of making the two products where the apple supply and the manufacturing conditions are suitable. The development of this infant industry must now be left in the hands of the progressive American manufacturer. A process which will make pure, fresh cider available as a summer drink at our soda fountains should open up a new and valuable market for the juice of surplus apples. Whether young America will eat apple sirup on his bread and his mother use it in her kitchen must be decided by the American people.

Similar considerations are being applied to other fruits now wasted.

The "dairy lunch" rooms of our cities and larger villages represent an innovation in dietary practice. The dinner pail and the lunch basket filled with home-made food have given way to 
"ready-made meals." To one group of persons the "lunch rooms" represent a welcomed escape from the more expensive luxuries of the conventional restaurant; likewise a possibility of substituting old-fashioned pastry and cereal dishes for the usual dining room meal rich in meat. To another, increasing class, however, they offer a means of reducing the labor of the household by the device of a public eating place. The recent interesting study of a familiar chain of these "dairy" restaurants, published under the auspices of the Sage Institute by Gephart and Lusk, ${ }^{13}$ show that the popular sandwich meal of the lunch counters is by no means a cheap diet for the working classes who have a limited allowance to spend for food. Attractive as the highly profitable service of the "dairy lunch" may be, with its congenial environmental features, it cannot compete with "home cooking" from the standpoint of economy. This lesson needs to be brought home to a nation which is continually discussing the high

13 Gephart, F. C., and Lusk, G.: Analysis and Cost of Ready-to-serve Foods. Press of the American Medical Association, Chicago 1915. 
cost of living. Domestic arts should not become relegated entirely to corporate enterprise.

Changing Social and Industrial Conditions and Other Economic and Hygienic Factors.-Rubner has pointed out an interesting effect of commerce in food on nutrition.

"Most conservative as to the food question," he remarks, "is the farmer, though in the country, too, many changes are taking place. He has frequent contact with the city, but he has still plenty of food material though not always quite suitable to the purpose. I have noticed a very unfavorable influence of urban food requirements on the milk producing districts of some regions of Switzerland and Germany, which is so characteristic that it deserves consideration. The milk producing regions of the Bavarian highlands and of Switzerland had formerly an extremely healthy, strong, and temperate population. Milk was largely used as a food, and the excess of production was placed on the market. In the course of years 


\section{THEIR RELATION TO NUTRITION 45}

the communities gradually established central dairies in which the fat is withdrawn from the milk by means of centrifugal machines to produce cream and butter. The impoverished milk is partly returned to the farmers. The milk producers are paid in cash for their product, but a poor and insufficient food takes now the place of a former healthy one. The money now goes to the saloons. The potato conquers a new territory. Instead of the butter which was formerly used, cheap fats are now bought; in short, the change of diet is exactly such as we find with the poorer working population in the cities. The effects are exactly the same. Physical deterioration in such districts becomes more and more pronounced, reaching finally a low level. This is a very serious condition, which attracts attention and which must be combated by all possible means."

Rubner believes, further, that the industrialization of nations is attended by a change in body 
weight, not because the race has changed in itself, but because the nutritive conditions have changed for a large number of laboring people through migration to the cities. Today only a small proportion of the industrial establishments are in rural communities, where the living conditions are favorable. The problem of the under-fed is thus closely related to the distribution of the food supply.

The present European war is affording an opportunity to study the relation of the food supply to unexpected economic and territorial conditions. From the standpoint of Germany the situation is unique in view of the exclusion of food normally obtained in large amounts from abroad. Russia, America, and other countries have hitherto furnished wheat, rice, butter, lard, eggs, and many other foods, along with cruder feeds which in turn were applied to animal production. These sources have been threatened or entirely cut off. With real scientific acumen the German nation has started a public propaganda 


\section{THEIR RELATION TO NUTRITION 47}

of advice intended to meet the situation thus unexpectedly created. ${ }^{14}$ The export of native products, such as sugar and rye, is to be restricted; the feeding of materials suitable for human consumption to cattle is to be greatly decreased and conservation of food values ordinarily lost in the processes of conversion into animal tissue accomplished; unjustifiable waste is to be avoided not only in the trade at large but in the individual kitchen. The elaborateness of the investigation is indicated by such details as the reminders that 20 grams of fat per capita are lost in the sewage waste of Berlin every day, and that this ought to be prevented. The people are assured, on the authority of eminent scientists, that they need not fear intelligently instituted changes of dietary régime as something inimical to health. The laws of nutrition and suitable dietetic advice are being proclaimed and dis-

14 Eltzbacher, P.: Die Deutsche Volksernährung und der Englische Aushungerungsplan. Fr. Vieweg \& Sohn, Braunschweig 1915. 
tributed in popular form. ${ }^{15}$ The more liberal use of plant products (rich in carbohydrates) in place of meats (rich in proteins and fats) is urged. As a move in the direction of economy in nutrition the gradual substitution of the regimen of South German households in place of the excessive meat diet of the northern provinces is urged. Even a cook-book for war times is freely supplied. ${ }^{16}$

The experience of the commissary department of the United States Army in Cuba during the campaign of 1898 has taught the mistake not only of disregarding local conditions, but also of failing to grasp important dietary principles and to inculcate them where the lessons are needed.

No presentation of the problems of the food supply would be complete without an appreciation of what the growing science of physiology and the chemistry of foods is contributing to mankind.

15 For example, in pamphlets such as "Ernährung in der Kriegszeit," ein Ratgeber von Prof. Dr. Paul Eltzbacher, Frau Hedwig Heyl, Prof. Dr. Carl Oppenheimer, Prof. Dr. Max Rubner und Prof. Dr. Nathan Zuntz. Braunschweig 1915.

18 For example, the "Kriegskochbuch" von Frau Hedwig Heyl. Berlin 1915. 


\section{THEIR RELATION TO NUTRITION 49}

The calorie-idea in nutrition, the outcome of an understanding of the transformation of energy in the living body, has been fruitful in more ways than one. It has taught people to think of the uses of food from a more rational standpoint and has furnished an intelligible basis for constructive institutional dietetics as well as the nutrition of the individual. Food is beginning to be regarded as fuel for the human organism-something that must be provided in determinable amounts. Malnutrition and undernutrition have received a new popular significance in the discussion of human efficiency.

This is not the place to discuss the limitations of the calorie-idea in nutrition or of some of the current conceptions of the rôle of the individual nutrients - the proteins, fats, carbohydrates, and inorganic salts. There is a well-founded growing belief that an important part in nutrition is played by substances which are not identical with the familiar foodstuffs mentioned and which, despite the minimal amounts thereof present in the diet, may nevertheless be indispensable for growth 
and the maintenance of life. They have been called "accessory diet factors" or "vitamins." We may conceive of them as stimulating certain physiological processes and as essential to certain functions.

The lubricant is quite as important to a machine as is the energy-furnishing fuel. So these diet accessories may have a peculiar usefulness. Some of them are believed to be easily impaired by heat; in the language of the chemist, they may be thermolabile. Hence the use of heat for preserving or sterilizing foods suggests new difficulties. They may sometimes be lost in the wastes of the modern technical processes, as in the milling of cereals. This has been demonstrated in the case of "polished" rice. They may be sensitive to other agencies involved in the change from fresh to salted or "prepared" or preserved foods.

These topics represent the border line of our knowledge of today. Enough facts are known, however, to justify the interest which the subject is receiving. Scurvy has long been recognized as a disease related to diet, and the antiscorbutic 


\section{THEIR RELATION TO NUTRITION 51}

and curative virtues of certain food products like lemon juice were early learned by experience. To these so-called "deficiency diseases," beri-beri and possibly pellagra, rickets, and Barlow's disease may be added. I have discussed special features of this question elsewhere. ${ }^{17}$ They help to explain the occasional failure of one-sided dietaries, and possibly the incidence of disease in groups of people living through ignorance under restricted conditions of diet, in institutions, on expeditions, on shipboard, during famine, and sometimes amid plenty.

The danger, if there be such, of a lack of unrecognized diet accessories is probably greatest in the exclusive use of "artificial" foods which have experienced extensive alterations in the course of their commercial preparation. In the present stage of our knowledge, variety of food, including fresh foods of many descriptions, may be welcomed on this ground alone. Canned goods,

17 Mendel, L. B.: Nutrition and Growth. The Harvey Society Lectures, 1914-15. Also Journal of the American Medical Association, May 8, 1915, p. 1539. The literature of the subject is presented there in some detail. 
glucose, margarine, refined sugar, highly milled cereals-in themselves skillfully produced specimens of modern technical progress-should be supplemented with fresh foods for safety until our knowledge has grown to supersede the uncertainty of present-day ignorance about unappreciated deficiencies of the diet. If the factory and organized business have introduced "artificial" products, modern industrial organization and transportation have likewise increased the possibilities of physiological liberality in diet. The studies of the past few years on the physiology and chemistry of the ripening of fruits is only one indication of how science is enlarging the possibilities of the food supply through an understanding of underlying factors. Useful investigations on the date, the banana, the apple, and other fruits have already been instituted by our government.

The recent progress in the physiological chemistry of the proteins illustrates a trend that is likely to affect feeding practices in the future. The protein molecule is composed of a group of unlike chemical units, many of which appear to 


\section{THEIR RELATION TO NUTRITION 53}

be indispensable for the nutritive functions. ${ }^{18}$ The animal body cannot construct all of these synthetically, hence it is dependent upon a supply thereof in the diet. The proteins of common foods furnish unlike yields of these essential units or tissue "building stones." It is accordingly becoming apparent that a well-selected ration must furnish these in both quantitative and qualitative sufficiency. Corn and the by-products of the maize kernel are notably inadequate for good feeding results unless they are supplemented by other protein-containing foods. The relative economy of the addition of supplementary proteins; such as are present in dried blood or milk products, to a ration that is inexpensive, but inefficient by itself, suggests new standards in our feeding practices. A small addition of an adequate protein may be far more advantageous for producing gains in animal husbandry than large amounts of cheaper proteins which supplement the

18 For a detailed discussion of this subject consult Underhill, F. P.: The Physiology of the Amino Acids. Yale University Press 1915. 
deficiency of the basal ration less well. ${ }^{10}$ Our Agricultural Experiment Stations are becoming alive to the opportunities here opened. Fodder analysis has taken a new turn. ${ }^{20}$ It is probable that protein feeding in the future will be based on the known chemical structure of the feeds quite as much as on the results of past feeding experiments.

19 Cf. Osborne, T. B., and Mendel, L. B.: Feeding Experiments Relating to the Nutritive Value of the Proteins of Maize. Journal of Biological Chemistry, 1913, xiv, p. xxxi; Nutritive Properties of Proteins of the Maize Kernel. Journal of Biological Chemistry, 1914, xviii, 1; Osborne, T. B.: The Nutritive Value of the Proteins of Maize. Science, 1913, xxxvii, 185; Osborne, T. B., and Mendel, L. B.: The Comparative Nutritive Value of Certain Proteins in Growth, and the Problem of the Protein Minimum. Journal of Biological Chemistry, 1915, xx, 351; Protein Minima for Maintenance. Ibid., 1915, xxii, 241.

${ }^{20}$ Cf. Nollau, E. H.: The Amino-acid Content of Certain Commercial Feeding Stuffs and Other Sources of Protein. Journal of Biological Chemistry, 1915, xxi, 611; Grindley, H. S., Joseph, W. E., and Slater, M. E.: The Quantitative Determination of the Amino-acids of Feeding Stuffs by the Van Slyke Method. Journal of the American Chemical Society, 1915, xxxvii, 1778; Hart, E. B., and Bentley, W. H.: The Character of the Water-soluble Nitrogen of Some Common Feedingstuffs. Journal of Biological Chemistry, 1915, xxii, 477; Buckner, G. D., Nollau, E. H., and Kastle, J. H.: The Feeding of Young Chicks on Grain Mixtures of High and Low Lysine Content, American Journal of Physiology, 1915, xxxix, 162. 


\section{THEIR RELATION TO NUTRITION 55}

Here, as so often before, the investigations of what is sometimes contemptuously referred to as "pure" science have furnished results of great importance to practical nutrition. Sir William Crookes, whose forecast of the failing wheat supply has been referred to, could scarcely foresee that the progress of physiological chemistry might in itself nullify the contentions which he vigorously defended.

A corollary of a better understanding of the principles involved in the field of human nutrition is the improvement of household science and the domestic arts. Herein lies the significance of the notable "home economics movement" of the present time. Nutrition and its relation to the food supply is in no small measure a problem of the home. Just as the lessons of modern science are permeating the practices of up-to-date agriculture, so they ought to influence and modify the performance of the household. The latter has been described as a social institution employing certain material agencies which include the provision of food and clothing. Its relations to other 
social institutions are manifold. Upon industry, for example, the household exerts an influence by maintaining the physical vigor and efficiency of the worker; and industry, in turn, affects the home by the character of the supplies which it furnishes. We are told that the household is the ultimate agency in the distribution of economic wealth to individuals. ${ }^{21}$ What the wage-earner really secures and the wife and children secure, depend upon the efficiency with which the household turns the wage-income into economic good, and, at the same time, supplements it by the income-equivalent of household work. The contribution of productive household work is too little emphasized. The home can become responsible for malnutrition and insanitary living. An appreciation of food costs, of efficient marketing, of the "casual sequence of food from the farm to the dining room," of the preparation of food for the table, surely is of fundamental import in every home. The culinary art, upon which so much may de-

21 Cf. Andrews, B. R.: A Course in Household Economics. Journal of Home Economics, February, 1913, p. 26. 


\section{THEIR RELATION TO NUTRITION 57}

pend, is in danger of deteriorating in the homes of this country. The admonition to "cook at home" should be passed on to the less well-to-do classes and the education of their young in the applications of domestic science should be warmly defended. No baker's bread equals the best homemade product. Too few women of the working classes are equipped to meet the demands which the home should properly make upon them.

Many years ago Liebig wrote, in his Familiar Letters on Chemistry:

Among all the arts known to man, there is none which enjoys a juster appreciation, and the products of which are more universally admired, than that which is concerned in the preparation of our food. Led by an instinct, which has almost reached the dignity of conscious knowledge, as the unerring guide, and by the sense of taste, which protects the health, the experienced cook, with respect to the choice, the admixture, and the preparation of food, has made acquisitions surpassing all that chemical and physiologi- 
cal science has done in regard to the doctrine or theory of nutrition. In soup and meat sauces, he imitates the gastric juice; and by the cheese which closes the banquet, he assists the action of the dissolved epithelium of the stomach. The table, supplied with dishes, appears to the observer like a machine, the parts of which are harmoniously fitted together, and so arranged, that, when brought into action, a maximum of effect may be obtained by means of them. The able culinary artist accompanies the sanguigenous matter with those which promote the process of solution and sanguification, in due proportion; he avoids all kinds of unnecessary stimuli, such as do not act in restoring the equilibrium; and he provides the due nourishment for the child as well as the old man, as well as for both sexes.

Even Liebig, the great scientist, could not adequately visualize the application of science in the kitchen. Man no longer depends upon his instincts alone for guidance in the affairs of life; 


\section{THEIR RELATION TO NUTRITION 59}

otherwise progress would indeed be slow. Instruction in domestic science ought to become a means of solving the problems of applied nutrition; and the best interests of the home-economic as well as social-call for better domestic service, a discipline into which woman will enter "mit Lust und Liebe."

We have seen that the problem of food supply is not one which can be dismissed by the social philosopher or solved by the calculations of the economist. It is highly complex with its involvement of factors and interests in agriculture, commerce, industry, and nutrition. Here, as in other domains, there is opportunity for an interplay of science and the arts, of experience and investigation. To attempt to foretell the future seems more like an act of ill-considered rashness than a keen intellectual venture. The truth can only be approached scientifically. We are beginning to learn what real food values mean. There is as yet no ideal ration. The "world-menu" is not in sight. Fitting indeed on this occasion are the words of Professor Rubner: 
The nutrition of the great mass of the people is a question of the highest importance, deserving far more attention than it has hitherto received. All the great countries ought to have a central authority, a food commission, which should concern itself exclusively with the far-reaching questions of the well-being of the people. The material, as it lies before us today, is very incomplete, but suffices to indicate the main lines of useful work. The nutrition of the masses has so far been mostly studied with regard to political economy and according to methods and viewpoints which do not always withstand the tests of the physiology of nutrition. Only by means of the physiology of nutrition is it possible to carry on exact research.

The nutrition of the masses is to us a problem which may be approached and improved from many sides. It is necessary that not only the hygienists, in the narrower sense, take up the struggle for betterment, 


\section{THEIR RELATION TO NUTRITION 61}

but that also the great army of men, who are truly humane in their hearts, shall take their places beside us. The battle which we have to carry on is not only against unavoidable and natural difficulties; we must not forget that human society includes many elements, unwilling to make the least concession to a humanitarian movement, persons whose prosperity is selfishly held superior to the welfare of their neighbors, and who will oppose such a movement with all the means at their command. Let us hope that our opponents will, at the last, rejoice with us in a triumph of the Humane Idea. ${ }^{22}$

22 Rubner, M.: The Nutrition of the People. Journal of Home Economics, 1913, v, 1. 







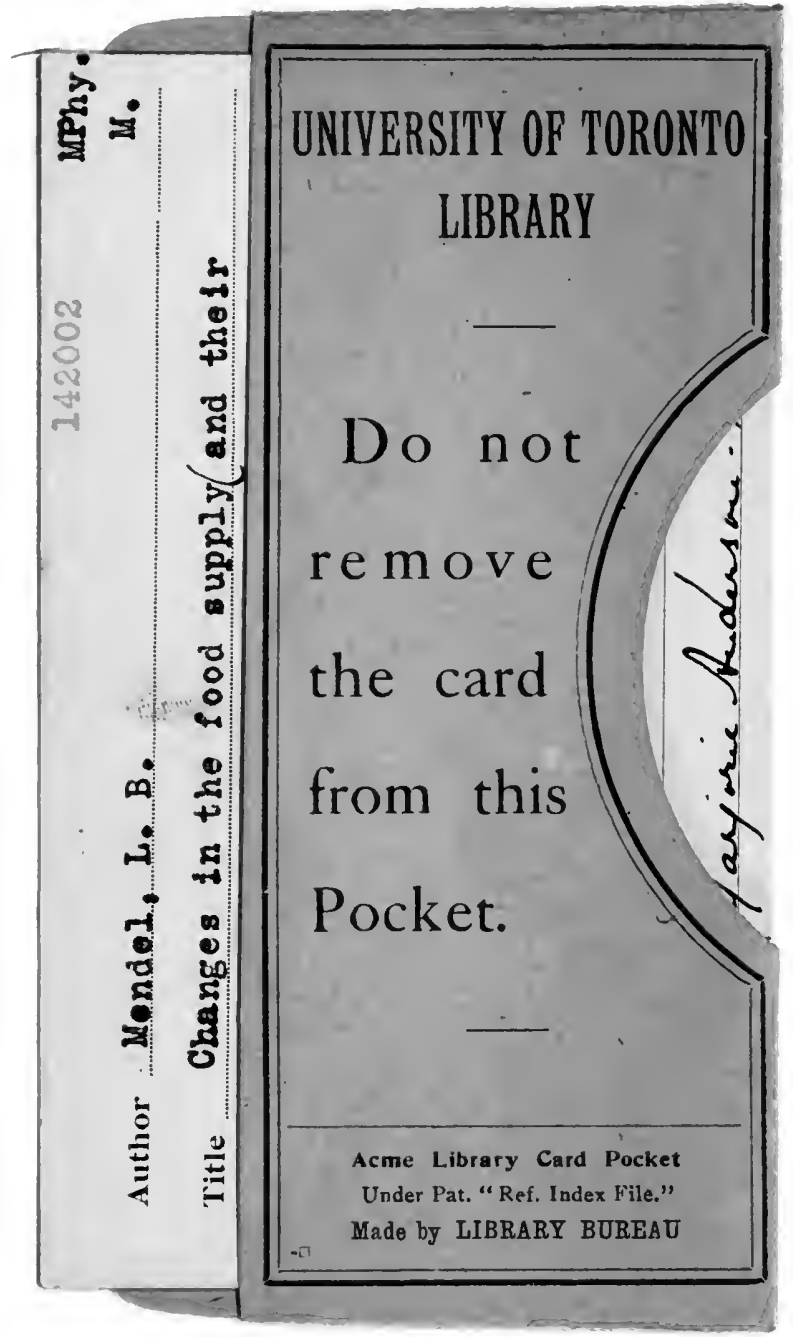


